\title{
PEMBERDAYAAN ANGGOTA KELOMPOK WANITA TANI MELALUI OPTIMALISASI PEKARANGAN PANGAN LESTARI DI KECAMATAN PALIMANAN KABUPATEN CIREBON
}

\section{Empowering women farmer group members through optimizing suistanable food yards in Palimanan sub-district Cirebon Regency}

\author{
Asri Suhartianah $^{1^{*}}$, Tri Ratna Saridewi ${ }^{1}$ Nazaruddin $^{1}$ \\ ${ }^{1}$ Politeknik Pembangunan Pertanian Bogor \\ *Email: asrisuhartiana@gmail.com
}

\begin{abstract}
The proper use of yard land greatly contributes to food security and health. The problem faced is that the knowledge of housewives about agricultural cultivation techniques is still low, so it is necessary to empower for the use of yard land. This research aims to (1) describe empowerment (2) analyze the factors that influence empowerment (3) develop a strategy for empowering women farmer group members through optimizing sustainable food yards. The research was conducted in Palimanan District, Cirebon Regency, starting from April to July 2021. The entire population of this research was 53 people spread over 3 selected villages. Data were analyzed descriptively and multiple linear regression analysis. The results showed that the empowerment of women farmer groups in Palimanan District was in the moderate category. Factors that influence the empowerment of women's farmer groups are age, function of women's farmer groups, support for extension services, and environmental support. The strategies for empowering women farmer groups through optimizing sustainable food yards are: 1) Conducting discussions together by approaching adults and sharing experiences 2) Carrying out intensive use of yard land by improving the quality of counseling 3) Improving the functions of women farmer groups including: class learning, cooperation vehicles, and production units. 4) Increasing the empowerment of women's farmer groups towards agricultural business through the use of yard land through.
\end{abstract}

Keywords: empowerment, yard,the kelompok wanita tani empowerment

\begin{abstract}
ABSTRAK
Pemanfaatan lahan pekarangan secara tepat sangat berkontribusi pada ketahanan dan kesehatan pangan. Permasalahan yang dihadapi adalah pengetahuan ibu-ibu rumah tangga tentang teknik budidaya pertanian masih rendah, sehingga perlu dilakukan pemberdayaan untuk pemanfaatan lahan pekarangan. Penelitian ini bertujuan untuk (1) mendeskripsikan keberdayaan (2) menganalisis faktor-faktor yang mempengaruhi keberdayaan (3) menyusun strategi pemberdayaan anggota kelompok wanita tani melalui optimalisasi pekarangan pangan lestari. Penelitian dilakukan di Kecamatan Palimanan Kabupaten Cirebon dimulai Bulan April sampai dengan Bulan Juli 2021. Responden penelitian ini seluruh populasi sebanyak 53 orang yang tersebar di 3 desa terpilih. Data dianalisis deskriptif dan analisis regresi linear berganda. Hasil penelitian menunjukan bahwa keberdayaan anggota kelompok wanita tani di Kecamatan Palimanan termasuk kategori sedang. Faktor-faktor yang mempengaruhi keberdayaan kelompok wanita tani adalah umur, fungsi kelompok wanita tani, dukungan layanan penyuluhan, dan dukungan lingkungan. Strategi pemberdayaan kelompok wanita tani melalui optimalisasi pekarangan pangan lestari yaitu: 1) Melakukan diskusi bersama-sama dengan melakukan pendekatan orang dewasa dan berbagi pengalaman 2) Melaksanakan kegiatan pemanfaatan lahan pekarangan secara intensif dengan meningkatkan kualitas penyuluhan 3) Meningkatkan fungsi kelompok wanita tani diantaranya: kelas belajar, wahana kerjasama, dan unit produksi. 4) Peningkatan keberdayaan kelompok wanita tani terhadap usaha bidang pertanian melalui pemanfaatan lahan pekarangan melalui.
\end{abstract}

Kata Kunci: keberdayaan, pekarangan, pemberdayaan kelompok wanita tani 


\section{Pendahuluan}

Kabupaten Cirebon mengalami peningkatan jumlah penduduk dari 2.192.903 jiwa naik menjadi 2.270.621 jiwa. Kepadatan penduduk naik dari 2.049/km2 menjadi 2.122/km2 (BPS 2021). Hal ini menyebabkan adanya kebutuhan yang terus meningkat setiap hari. Peningkatan jumlah penduduk ini sangat menuntut penyediaan kebutuhan pangan yang cukup. Pemenuhan kebutuhan pangan dapat dilakukan mulai dari rumah tangga dengan lahan yang terbatas dan tanah yang sempit.

Kecamatan

Palimanan

merupakan salah satu kecamatan di wilayah Kabupaten Cirebon dengan luas wilayah berupa daratan seluas 18,16 $\mathrm{km} 2$. Luas lahan pekarangan di Kecamatan Palimanan adalah $199 \mathrm{Ha}$ atau $25 \%$ dari luas seluruh tanah darat pertanian (BPP 2020). Masyarakat Kecamatan Palimanan rata-rata memiliki rumah dengan lahan pekarangan yang cukup luas. Lahan pekarangan tersebut masih belum dapat dimanfaatkan secara optimal.

Berdasarkan pengamatan yang dilakukan, sekitar $40 \%$ lahan pekarangan yang dimiliki hanya dibiarkan saja. Padahal, lahan pekarangan yang dapat dikelola dengan baik dapat memberikan manfaat bagi kehidupan keluarga, seperti untuk tempat bermain, sumber pangan, dan sumber pendapatan (Ashari et al. 2012). Lahan pekarangan yang luas memiliki potensi untuk dimanfaatkan melalui penanaman berbagai jenis tanaman, khususnya tanaman pangan (Dwiratna et al. 2016). Tanaman pangan tersebut di antaranya adalah sayur-sayuran, buah-buahan, dan rempah-rempah.

Keberadaan lahan pekarangan menjadi sebuah keharusan bagi masyarakat di pedesaan karena dorongan kultur sosial secara turun temurun. Salah satu manfaat terpenting dari pekarangan yang terus diwariskan oleh leluhur adalah sebagai pendukung pemenuhan kebutuhan keluarga (Dwiratna et al. 2016). Namun demikian, jenis tanaman yang umum dibudidayakanmasih sangat beragam bahkan dalam era modern tanaman hias lebih mendominasi pekarangan (Kartika 2018). Kondisi tersebut kini mulai bergeser, sejak munculnya pandemi Covid-19 yang mengakibatkan aktivitas masyarakat dibatasi memunculkan kenormalan baru yakni mengoptimalkan pekarangan untuk memenuhi kebutuhan sehari-hari.

Pemanfaatan lahan pekarangan, lahan tidur dan lahan kosong yang tidak produktif menjadi lahan produktif merupakan bagian dari Program Kegiatan Pekarangan Pangan Lestari yang dicanangkan oleh Kementerian Pertanian. Kegiatan P2L merupakan upaya untuk meningkatkan ketersediaan, aksesibilitas, dan pemanfaatan pangan bagi rumah tangga sesuai dengan kebutuhan pangan yang beragam, bergizi, seimbang dan aman serta berorientasi pasar untuk meningkatkan pendapatan rumah tangga. Berdasarkan hal tersebut untuk mencapai upaya dilakukan melalui pendekatan pengembangan pertanian berkelanjutan (sustainable agriculture), pemanfaatan sumber daya lokal (local wisdom), pemberdayaan masyarakat (community engagement) dan berorientasi pemasaran (go to market) (Pertanian 2020).

Di era globalisasi yang semakin maju saat ini banyak perempuan yang memilih bekerja atau menjadi wanita karir dibandingkan menjadi ibu rumah tangga biasa. Hal tersebut banyak terjadi di daerah perkotaan. Sedangkan di daerah pedesaan yang sebagian besar masyarakat berpendidikan rendah dan masih kental dengan adat/norma bahwa perempuan harus dirumah. Persentase perempuan Kabupaten Cirebon dalam mengurus rumah tangga sebesar $21,38 \%$ dari jumlah penduduk (BPS 2021).

Kondisi demikian membuat upaya pemberdayaan masyarakat semakin menjadi kebutuhan. Pemberdayaan merupakan upaya pemberian kesempatan dan memfasilitasi 
kelompok miskin agar mereka memiliki aksebilitas terhadap sumberdaya yang berupa: modal, teknologi, informasi, dan jaminan pemasaran, agar mereka mampu memajukan dan mengembangkan usahanya, sehingga memperoleh perbaikan pendapatan serta perluasan kesempatan kerja demi perbaikan kehidupan dan kesejahteraan (Mardikanto et al. 2013).

Salah satu bentuk komitmen pemerintah terhadap pemberdayaan kaum perempuan adalah dibentuknya Kelompok Wanita Tani (KWT) sebagai wadah kaum perempuan untuk mengaktualisasikan dirinya dalam rangka membantu pemenuhan kebutuhan pangan dalam rumah tangga. Implementasi dari keikutsertaan dalam Kelompok Wanita Tani (KWT) diantaranya ibu rumah tangga yang tidak memiliki lahan pertanian, dapat memanfaatkan lahan pekarangan untuk bercocok tanam. Berdasarkan permasalahan diatas, maka penelitian ini berjudul "Pemberdayaan Anggota Kelompok Wanita Tani melalui Optimalisasi Pemanfaatan Pangan Lestari di Kecamatan Palimanan Kabupaten Cirebon". Penelitian ini bertujuan untuk (1) mendeskripsikan keberdayaan (2) menganalisis faktorfaktor yang mempengaruhi keberdayaan (3) menyusun strategi pemberdayaan anggota kelompok wanita tani melalui optimalisasi pekarangan pangan lestari.

\section{Metode}

Pelaksanaan Penelitian tentang Pemberdayaan Anggota Kelompok Wanita Tani melalui Optimalisasi Pekarangan Pangan Lestari telah dilaksanakan pada bulan April sampai dengan Juni. Populasi penelitian ini adalah kelompok wanita tani di Kecamatan Palimanan. Penentuan desa atas rekomendasi penyuluh setempat dengan keaktifan anggota kelompok wanita tani dalam kegiatan penyuluhan dan pelatihan di bidang pertanian.

Pengambilan sampel dilakukan berdasarkan seluruh jumlah populasi dijadikan sampel sebanyak 53 orang anggota KWT yang ada di Kecamatan Palimanan. Hasil rekomendasi penyuluh dengan rincian kelompok wanita tani diantaranya Rukun Lestari yang berada di Desa Palimanan Timur berjumlah 20 orang, kelompok wanita tani Dewi Sri berada di Desa Lungbenda berjumlah 14 orang, dan kelompok wanita tani Nusa Indah di Desa Cengkuang berjumlah 19 orang. Jumlah populasi yang dijadikan sampel pada ketiga desa yang diteliti tersebut yakni sebanyak 53 orang wanita tani.

Instrumen yang digunakan dalam kegiatan penelitian berupa kuesioner. Kuesioner yang dibuat kuesioner terbuka atau kuesioner yang berisi daftar pertanyaan esai dengan kriteria jawaban yang telah ditentukan. Uji validitas dilakukan dengan cara membandingkan nilai $r$ hitung dengan $r$ tabel. Setelah didapatkan angka dari hasil perhitungan SPSS 25. Kemudian nilai $r$ hitung dari 15 responden dicocokan dengan $r$ tabel product moment pada taraf $5 \%$ yaitu $\geq 0,553$. Apabila hasil $r$ hitung lebih besar dari $r$ tabel maka butir soal tersebut dinyatakan valid. Pengujian reliabilitas instrumen dilakukan dengan membandingkan nilai Croncbach's alpha Suatu instrumen dinyatakan reliabel jika mempunyai nilai Croncbach's alpha $\geq 0,6$ (Sugiyono, 2013), diketahui seluruh soal reliabel karena nilainya melebihi 0,6 , dengan menggunakan aplikasi IBM SPSS Statistics 25 diketahui nilai alfa dari instrumen penelitian ini ialah 0,970 sehingga dikatakan reliabel.

Data yang dibutuhkan dalam penelitian ini meliputi data primer dan data sekunder. Data primer dikumpulkan secara langsung dari sumbernya yaitu melalui wawancara dengan responden sebanyak 53 orang. Data sekunder yang diambil adalah data pendukung yang berhubungan dengan penelitian dan bersumber dari instasi terkait seperti kondisi potensi wilayah, demografi, dokumentasi KWT, dokumentasi BPP Palimanan dan 
monografi Kecamatan Palimanan, data dari Kantor Desa dan data dari Instansi lainnya. Analisis deskriptif dilakukan dengan menggunakan distribusi frekuensi dan analisis inferensial menggunakan analisis regresi linier berganda. Salah satu syarat untuk menggunakan analisis regresi linear berganda adalah data harus berskala interval atau rasio. Penelitian ini menggunakan skala ordinal sehingga harus ditransformasikan menggunakan Method Succesive Interval (MSI). Persamaan regresi linear berganda dengan rumus sebagai berikut:

$Y=\alpha+\beta 1 X 1.1+\beta 2 \times 1.2+\beta 3 \times 1.3+$

$\beta 4 \times 1.4+\beta 5 \times 2+\beta 6 \times 3+\beta 7 \times 4$

Keterangan:

$\mathrm{Y}=$ Keberdayaan KWT

$\alpha=$ Konstanta

$\beta 1 \times 1.1=\quad$ Umur

$\beta 1 \times 1.2=\quad$ Lama Pendidikan

$\beta 1 \times 1.3=\quad$ Lama Berusahatani

$\beta 1 \times 1.4=\quad$ Luas Pekarangan

$\beta 2 \times 2=$ Fungsi Kelompok

WanitaTani

$\beta 3 \times 3=$ Dukungan Layanan $\beta 4 \times 4 \quad=\quad$ Dukungan
Lingkungan

Hasil dan Pembahasan

\section{Karakteristik Responden}

Karakteristik responden
merupakan faktor internal yang
mencirikan atau mengidentitaskan
seorang individu, biasanya
mempengaruhi individu tersebut dalam
pengambilan keputusan dan
kemandirian dari individu tersebut.
Responden dalam kegiatan Penelitian
ini adalah ibu-ibu yang tergabung ke
dalam kelompok wanita tani dan pernah
menerima materi Pemanfaatan
Pekarangan Pangan Lestari (P2L) di
Kecamatan Palimanan Kabupaten
Cirebon. Responden memiliki latar
belakang dan karakteristik yang
berbeda-beda. Berdasarkan hal
tersebut dalam Penelitian ini
karakteristik responden yang dianalisis
yaitu umur, lama bersekolah, lama
berusahatani, dan luas pekarangan.

Karakteristik responden merupakan faktor internal yang atau mengidentitaskan biasanya mempengaruhi individu tersebut dalam pengandian dari individu tersebut. Responden dalam kegiatan Penelitian ini adalah ibu-ibu yang tergabung ke dalam kelompok wanita tani dan pernah menerima materi Pemanfaatan Pekarangan Pangan Lestari (P2L) di Kecamatan Palimanan Kabupaten Cirebon. Responden memiliki latar belakang dan karakteristik yang berbeda-beda. Berdasarkan hal karakteristik responden yang dianalisis berusahatani, dan luas pekarangan.

Tabel 1. Karakteristik Responden

\begin{tabular}{cllccc}
\hline No. & \multicolumn{1}{c}{ Indikator } & \multicolumn{1}{c}{ Kategori } & Umur & $\mathbf{n}$ & $(\%)$ \\
\hline 1. & Umur (Tahun) & Muda & $19-33$ Tahun & 6 & 11,32 \\
& Dewasa & $34-46$ Tahun & 30 & 56,60 \\
& Tua & $47-61$ Tahun & & 32,08 \\
2. Lama Pendidikan & Rendah & SD & 10 & 18,87 \\
& (Tahun) & Sedang & SLTP & 17 & 32,08 \\
& Tinggi & SLTA & 23 & 43,40 \\
& Sangat Tinggi & PT & 3 & 5,66 \\
3. Lama berusahatani & Kurang Berpengalaman & $\leq 5$ tahun & 40 & 75,47 \\
& (Tahun) & Cukup Berpengalaman & $6-10$ tahun & 13 & 24,53 \\
& Berpengalaman & $11-15$ tahun & 0 & 0 \\
& Sangat Berpengalaman & $\geq 16$ tahun & 0 & 0 \\
4. Luas Pekarangan & Strata I & $<1 \mathrm{~m}^{2}$ & 0 & 0 \\
& (m²) & Strata II & $1 \mathrm{~m}^{2}-2 \mathrm{~m}^{2}$ & 25 & 47,17 \\
& Strata III & $3 \mathrm{~m}^{2}-5 \mathrm{~m}^{2}$ & 10 & 18,87 \\
& Strata IV & $6 \mathrm{~m}^{2}-10 \mathrm{~m}^{2}$ & 12 & 22,64 \\
& Strata V & $>10 \mathrm{~m}^{2}$ & 6 & 11,32 \\
\hline
\end{tabular}

Sumber: Data Primer (2021)

Sebagian besar responden berada pada kategori dewasa umur 34 sampai dengan 46 tahun dengan porsi
$56,60 \%$. Produktivitas seseorang dalam hal ini wanita tani ketika melakukan suatu pekerjaan tergantung dari umurnya. Ketika umurnya semakin tua 
maka produktivitas seseorang dalam melakukan pekerjaan semakin berkurang (Masalamate et al, 2015). Setiawan (2010) berpendapat bahwa produktivitas kerja dikaitkan dengan tingkatan usia yang produktif, karena golongan usia muda lebih produktif dibandingkan dengan golongan usia tua. Seperti halnya yang terjadi pada responden dalam penelitian ini sebagian besar berada pada golongan usia sangat produktif. Sari, et al (2016) mengungkapkan bahwa umur memiliki peran yang penting dalam menggapai keberhasilan usaha karena umur akan mempengaruhi daya ingat, produktivitas, keberanian untuk mengambil resiko dan pola pikir dalam menerima inovasi dalam berusahatani.

Sebanyak $43,40 \%$ responden yang berpendidikan Sekolah Lanjut Tingkat Atas (SLTA). Hal ini menandakan bahwa tingkat pendidikan anggota KWT yang berada di Kecamatan Palimanan ini sudah sangat tergolong baik. Saputra et al. (2016), pola fikir dan pengambilan keputusan dalam berusahatani akan ditentukan oleh tingkat pendidikan dan pengetahuan seseorang. Pendidikan menjadi salah satu tolak ukur seseorang berperilaku dalam masyarakat, tinggi rendahnya tingkat pendidikan seseorang akan mempengaruhi pola pikir dalam mengelola usahataninya (Masalamate et al, 2015). Sebagian besar tingkat jenjang pendidikan responden berada pada tingat Sekolah Lanjut Tingkat Akhir (SLTA). Hal ini akan memengaruhi dalam proses penangkapan suatu informasi yang disampaikan, karena semakin tinggi tingkat pendidikan maka penyampaian informasi akan maksimal.

Lamanya berusahatani yang dilakukan sebagian besar responden yaitu terdapat 40 orang tergolong kategori kurang berpengalaman $(\leq 5$ tahun) sebesar $75,47 \%$. Semakin lama seseorang dalam berusahatani, maka pengalaman berusahatanipun semakin banyak. Pengalaman dijadikan sebuah pelajaran untuk pengambilan keputusan dalam mengambil suatu tindakan. Pernyataan tersebut selaras dengan pernyataan Farahdiba et al. (2020) pengalaman berusahatani merupakan faktor penting dalam menerapkan pemanfaatan lahan pekarangan. Suaedi et al. (2013) dengan memiliki pengalaman bertani hal ini dapat mempengaruhi terhadap cara, keahlian serta kemampuan dalam bidang pertanian.

Kategori paling tinggi yaitu strata II dengan jumlah responden sebanyak 25 orang atau 47,17\%. Hal ini sejalan dengan pendapat Metalisa (2014) \& Irwan et al. (2015), dengan adanya lahan yang cukup luas ini dapat dijadikan salah satu keuntungan karena dengan lahan yang luas tersebut memungkinkan untuk ditanami dengan berbagai macam jenis tanaman. Sedangkan dengan lahan yang sempit atau terbatas maka beberapa teknik pemanfaatan lahan pekarangan perlu dilakukan seperti menggunakan pot, polybag, vertikultur maupun hidroponik agar dapat dimanfaatkan secara maksimal.

\section{Fungsi Kelompok Wanita Tani}

Fungsi kelompok wanita tani dalam pengkajian ini merupakan seperangkat fungsi kelompok wanita tani yang berkaitan dengan segala sesuatu yang berhubungan dengan kegiatan operasional anggota kelompok wanita tani dalam menjalankan kegiatan usahataninya berdasarkan pada prinsip tiga fungsi kelompok wanita tani seperti: a) kelas belajar; b) wahana kerjasama; dan c) unit produksi. Fungsi kelompok wanita tani dalam Penelitian ini dibagi kedalam 3 kategori yaitu rendah, sedang, dan tinggi. 
Tabel 2. Fungsi Kelompok Wanita Tani

\begin{tabular}{ccccc}
\hline No. & Kategori & Kisaran Nilai & Banyak Sampel (n) & Persentase (\%) \\
\hline 1. & Rendah & $0-40$ & 19 & 35,85 \\
2. & Sedang & $41-80$ & 34 & 64,15 \\
3. & Tinggi & $81-120$ & 0 & 0 \\
\hline & Jumlah & & 53 & 100 \\
\hline
\end{tabular}

Sumber: Data Primer (2021)

Data Tabel 2 diatas

menunjukkan bahwa sebagian besar responden menilai bahwa fungsi kelompok wanita tani termasuk kedalam kategori sedang $(64,15 \%)$ sebanyak 34 orang, sebanyak 19 orang (35,85\%) menilai bahwa fungsi kelompok wanita tani termasuk kedalam kategori rendah. Hal ini dapat diartikan bahwa kelompok wanita tani yang ada di Kecamatan Palimanan keberadaanya cukup berperan dalam kegiatan usahatani.

$$
\text { Rendahnya kesadaran }
$$

responden di Kecamatan Palimanan untuk melakukan kegiatan pertemuan dengan kelompok wanita tani berdampak pada peran penyuluh dalam penyampaian materi pemanfaatan lahan pekarangan. Hal ini juga berkaitan dengan keadaan yang sedang mengalami pandemi Covid-19 sehingga penyebaran informasi dilakukan dengan metode dan media yang menyesuaikan keadaan.

Berdasarkan hasil wawancara bahwa kelompok wanita tani masih kurang berperan dalam kegiatan usahatani yang dilakukan oleh anggota kelompok wanita tani. Anggota dalam kelompok wanita tani belum mampu dalam merencanakan 1) kebutuhan belajar; 2) pertemuan/musyawarah; 3) pemanfaatan sumberdaya; 4) kegiatan pelestarian lingkungan, selain itu anggota KWT belum memiliki kemampuan merencanakan kegiatan usaha seperti usaha berdasarkan analisa usaha, peningkatan usaha, peningkatan produk sesuai permintaan pasar, pengelolaan dan pemasaran hasil, hingga penyediaan jasa. Perubahan pola pikir akan dapat dicapai apabila fungsi kelas belajar, wahana kerjasama, dan unit produksi kelompok tani dapat dilaksanakan secara maksimal.

\section{Dukungan Layanan Penyuluhan}

Dukungan penyuluhan adalah suatu usaha atau kegiaan yang dilakukan oleh penyuluh untuk membantu petani dalam usahataninya terdiri dari kegiatan penyuluhan, kompetensi penyuluh, ketepatan metode penyuluhan, kesesuaian materi penyuluhan dan intensitas penyuluhan (Suyadi, 2018).

Tabel 3. Dukungan Layanan Penyuluhan

\begin{tabular}{ccccc}
\hline No. & Kategori & Kisaran Nilai & Banyak Sampel (n) & Persentase (\%) \\
\hline 1. & Rendah & $0-40$ & 21 & 39,62 \\
2. & Sedang & $41-80$ & 32 & 60,38 \\
3. & Tinggi & $81-120$ & 0 & 0 \\
\hline & & & 53 & 100 \\
\hline
\end{tabular}

Sumber: Data Primer (2021)

Dukungan penyuluhan dalam kajian ini terdiri dari peran penyuluh, ketepatan metode penyuluhan, kesesuaian materi penyuluhan, dan kesesuaian media penyuluhan. Berdasarkan Tabel 3, bahwa sebagian besar responden menilai dukungan layanan penyuluhan masuk pada kategori sedang sebanyak 32 orang dengan persentase $60,38 \%$. Serta terdapat 21 orang responden $39,62 \%$ menilai bahwa dukungan layanan penyuluhan kedalam kategori rendah. Hal tersebut berarti bahwa layanan penyuluhan yang diselenggarakan oleh pihak penyuluh maupun BPP belum berjalan dengan baik. 
Menurut Zulvera (2014),
penyuluhan pada hakekatnya
merupakan suatu proses pendidikan
non formal yang ditujukan pada orang
dewasa yang bertujuan untuk
mengubah perilaku manusia sehingga
mau meninggalkan kebiasaan lama dan
menggantinya dengan perilaku baru
yang berakibat kualitas kehidupan orang
tersebut menjadi lebih baik.

Berdasarkan hasil wawancara bahwa kegiatan penyuluhan yang diselenggarakan oleh penyuluh di Kecamatan Palimanan masih jarang dilakukan. Materi yang disampaikan terkadang tidak sesuai dengan kebutuhan anggota KWT dan jarang sekali menggunakan media cetak dan media elektronik dalam kegiatan penyuluhan, sehingga anggota KWT cenderung bersikap acuh.

Media penyuluhan memiliki peranan yang cukup penting dalam kegiatan penyuluhan. Penggunaan media bertujuan untuk mencapai tingkat efektivitas dan efisiensi dari kegiatan penyuluhan. Kegiatan penyuluhan yang dilakukan oleh penyuluh di Kecamatan Palimanan seringkali hanya menggunakan metode ceramah, sehingga anggota kelompok wanita tani kurang mampu dalam memahami materi penyuluhan yang disampaikan. Selain itu dalam setiap kegiatan penyuluhan tidak ada pengawasan dan bimbingan, sehingga kegiatan atau program tidak berjalan secara berkelanjutan.

\section{Dukungan Lingkungan}

Dukungan lingkungan sosial adalah penilaian dari responden terhadap keadaan nyata di lapangan yang berhubungan dengan aktifitas kelompoktani, permodalan dan adanya kepastian harga pasar atas produk yang akan dihasilkan melalui kegiatan usahatani (Suyadi, 2018).

Tabel 4. Dukungan Lingkungan

\begin{tabular}{ccccc}
\hline No. & Kategori & Kisaran Nilai & Banyak Sampel (n) & Persentase (\%) \\
\hline 1. & Rendah & $0-40$ & 17 & 32,08 \\
2. & Sedang & $41-80$ & 36 & 67,92 \\
3. & Tinggi & $81-120$ & 0 & 0 \\
\hline \multicolumn{2}{r}{} & Jumlah & 53 & 100 \\
\hline
\end{tabular}

Sumber: Data Primer (2021)

Tabel 4 menunjukan bahwa mayoritas anggota kelompok wanita tani menilai bahwa dukungan lingkungan fisik dan sosial ekonomi berada pada kategori sedang sebesar 67,92 \%. Dukungan lingkungan fisik, dan sosial ekonomi meliputi dukungan sumberdaya lahan, dukungan lembaga agribisnis, dan dukungan pemerintah. Anggota kelompok wanita tani menilai bahwa dukungan lembaga agribisnis ini sangat dirasakan oleh responden terutama dalam proses penyediaan sarana dan prasarana pertanian yang dibutuhkan oleh responden dalam kegiatan usaha pertanian.

Kecamatan Palimanan memiliki kondisi agribisnis pertanian yang sangat potensial namun belum dimanfaatkan secara optimal. Pengairan yang cukup memadai yang bersumber dari mata air Gunung Ciremai. Sumberdaya lahan di Kecamatan Palimanan tergolong sedang $(83,02 \%)$. Lahan yang cukup memadai untuk melakukan budidaya di lahan pekarangan. Meskipun cuaca yang cukup ekstrem dengan suhu diatas $>25^{\circ} \mathrm{C}$.

Dukungan pemerintah di Kecamatan Palimanan mendapat nilai sebesar $62,26 \%$ atau 33 orang tergolong rendah. Fasilitas dan bantuan kebutuhan utama anggota kelompok wanita tani sangat mempengaruhi perilaku anggota KWT dalam melakukan usahatani. Rendahnya dukungan berupa fasilitas pelatihan untuk meningkatkan pengetahuan, sikap, dan ketampilan anggota KWT dalam pemanfaatan lahan pekarangan. 
Hal ini sejalan dengan penelitian Puspitasari et al. (2018) bahwa untuk meningkatkan perilaku kewirausahaan petani, pemerintah perlu memberikan dukungan fasilitas yang sesuai dengan apa yang dibutuhkan oleh petani seperti pelatihan. Bantuan penyediaan pupuk dan benih mempengaruhi perilaku anggota KWT karena untuk memberikan motivasi dan dorongan bagi anggota
KWT untuk memanfaatkan lahan pekarangan.

\section{Keberdayaan}

Keberdayaan anggota KWT dikategorikan menjadi 3 kategori berdasarkan analisis distribusi frekuensi yakni, rendah, sedang, dan tinggi. Hasil penelitian diperoleh keberdayaan anggota KWT di Kecamatan Palimanan yang disajikan pada Tabel 5.

Tabel 5. Keberdayaan Anggota Kelompok Wanita Tani

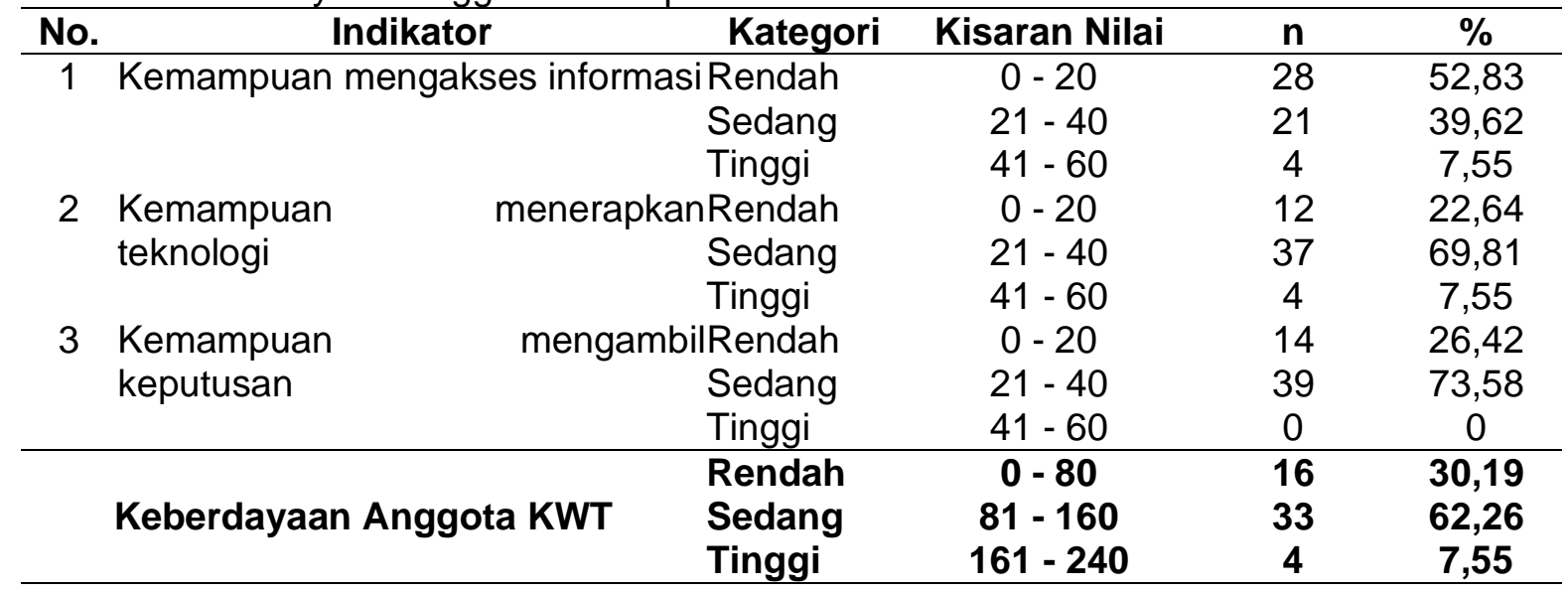

Sumber: Data Primer (2021)

Berdasarkan data yang tersaji pada Tabel 5 dapat diketahui bahwa sebagian besar kemampuan dalam mengakses informasi $(52,83 \%)$ memiliki kemampuan rendah, 39,62 \%. Menurut Sadono (2012) dalam penelitiannya menyatakan bahwa rendahnya kemampuan anggota KWT dalam mengakses informasi pertanian terkait dengan keterbatasan anggota KWT dalam mengakses informasi pertanian karena masih bertumpu pada informasi dari penyuluh dan sesama anggota KWT/tokoh tani/ anggota KWT dari luar desa melalui tatap muka. Hal tersebut sesuai dengan keadaan yang diperoleh dalam penelitian, rendahnya kemampuan responden dalam mengakses informasi karena keterbatasan yang dimiliki oleh responden itu sendiri sehingga responden hanya mengandalkan informasi yang diperoleh dari penyuluh dan sesama anggota KWT yang dinilai lebih berhasil.
Diketahui bahwa kemampuan anggota KWT dalam menerapkan teknologi budidaya sayuran di lahan pekarangan sebagian besar termasuk kedalam kategori sedang $(69,81 \%)$. Hasil wawancara dan hasil analisis data yang diperoleh, menunjukan kemampuan anggota KWT dalam menerapkan teknologi budidaya sayuran di lahan pekarangan tergolong dalam kategori sedang. Sebagian besar anggota KWT sudah menerapkan teknologi budidaya sayuran di lahan pekarangan. Jika dilihat dari karakeristik responden yang sebagian besar responden termasuk kedalam kategori cukup berpengalaman dalam berusahtani. Dalam pelaksanaan kegiatan budidaya, masih banyak responden yang belum menerapkan cara budidaya sayuran yang baik dan benar. Selain itu, pengetahuan dan keterampilan anggota KWT dalam penerapan teknologi budidaya sayuran masih tergolong sedang seperti menyiapkan media tanam, menyiapkan 
alat dan bahan, penyemaian, pengendalian OPT, penyiraman, pemupukan susulan dan panen.

Sebagian besar kemampuan dalam mengambil keputusan $(73,58 \%)$ memiliki kemampuan sedang, 26,42 \% responden memiliki kemampuan mengambil keputusan sedang dan tidak ada responden yang memiliki kemampuan tinggi dalam mengambil keputusan. Berdasarkan hasil wawancara dengan anggota KWT, sebagian besar sudah menerapkan teknologi budidaya sayuran di lahan pekarangan meskipun hanya sebagian rangkaian teknologi yang diterapkan. Pengambilan keputusan dalam memanfaatkan lahan pekarangan sebagai budidaya tanaman ditentukan oleh keluarga anggota KWT. Keikutsertaan anggota keluarga dalam pemanfaatan lahan pekarangan akan sangat menentukan pada proses budidaya. Luas pekarangan yang terdapat di masing-masing rumah responden sangat mempengaruhi hasil produksi. Anggota KWT yang memiliki luas lahan sempit / tanpa halaman cenderung kesulitan dalam penataan media pot/polybag.

\section{Faktor-faktor yang Mempengaruhi Keberdayaan}

Analisis secara parsial terhadap masing-masing variabel dapat diketahui bahwa umur, lama pendidikan, lama berusahatani, luas pekarangan, fungsi kelompok wanita tani, dukungan layanan penyuluhan, dan dukungan lingkungan dapat memberikan pengaruh terhadap keberdayaan dalam memanfaatkan lahan pekarangan (Sig < $0,05)$. Hasil pengujian dengan SPSS 25dapat dilihat pada Tabel 6 berikut:

Tabel 6. Hasil Analisis Regresi Linear Berganda

\begin{tabular}{lrrrl}
\hline \multicolumn{1}{c}{ Variabel } & \multicolumn{1}{c}{ Nilai } & \multicolumn{1}{c}{ T Hitung } & \multicolumn{1}{c}{ Sig. } & Keterangan \\
\hline Konstanta & 9,508 & 1,183 &, 243 & \\
Umur &, 424 & 3,122 &, 003 & Berpengaruh \\
Lama pendidikan &, 550 & 1,313 &, 196 & Tidak Berpengaruh \\
Lama Berusahatani &, 802 & 1,293 &, 203 & Tidak Berpengaruh \\
Luas Pekarangan &, 112 &, 604 &, 549 & Tidak Berpengaruh \\
Fungsi Kelompok Wanita Tani &, 853 & 2,175 &, 035 & Berpengaruh \\
Dukungan Layanan Penyuluhan &, 961 & 2,260 &, 029 & Berpengaruh \\
Dukungan Lingkungan &,- 857 & $-2,522$ &, 015 & Berpengaruh \\
\hline Nilai F Hitung & & $\mathbf{2 0 , 4 2 0}$ & $\mathbf{0 , 0 0 0}$ & Berpengaruh \\
\hline Adjusted R Square & $\mathbf{0 , 7 2 3}$ & & \\
\hline
\end{tabular}

Sumber: Data Primer (2021)

Hasil analisis diperoleh bahwa indikator umur, fungsi kelompok wanita tani, dukungan layanan penyuluhan dan dukungan lingkungan memiliki pengaruh signifikan terhadap keberdayaan anggota kelompok wanita tani. Nilai koefesien determinasi (Adjusted $R$ Square) sebesar 0,723, artinya bahwa pengaruh ketujuh variabel bebas $(X)$ terhadap variabel keberdayaan anggota kelompok wanita tani (Y) adalah sebesar 72,3\%. Sedangkan sisanya $27,7 \% \quad(100 \%$ $72,3 \%)$ dipengaruhi oleh variabel lain yang tidak ada didalam model regresi linear berganda.

\section{Pengaruh Umur Pada Keberdayaan}

Data Tabel 26 diketahui bahwa umur secara positif mempengaruhi keberdayaan kelompok wanita tani dalam pemanfaatan lahan pekarangan. Hal ini berarti bahwa semakin tinggi umur responden maka semakin tinggi keberdayaan. Kemudian diketahui bahwa responden di Kecamatan Palimanan rata-rata berumur 34 - 46 tahun dewasa Oleh karena itu pada usia dewasa ini anggota KWT akan lebih mudah diberdayakan maka kemampuan fisik, daya fikir dan respon akan terlihat.

Umumnya pada usia sangat produktif tingkat kemauan, semangat dan kemampuan untuk berusahatani 
cenderung lebih tinggi. Hal ini menunjukkan bahwa dengan usia yang sangat produktif, anggota KWT memiliki potensi yang cukup besar dalam pemanfaatan lahan pekarangan, semangat dan kemauannya lebih tinggi dibandingkan dengan responden yang sudah tua atau sudah tidak produktif. Responden yang sudah tua cenderung kuno dan percaya kepada kebiasaan yang sudah dijalankan oleh nenek moyangnya, sehingga rasa semangat dalam menerima dan melaksanakan teknologi baru akan sulit diterima (Richa et al. 2020).

Hal ini sejalan dengan hasil penelitian Hulyatussyamsiah et al. (2019) bahwa petani yang memiliki pendidikan tinggi lebih mudah dalam memahami informasi yang disampaikan, lebih responsif terhadap inovasi yang disampaikan dan memiliki keinginan untuk mencoba yang tinggi. Pengetahuan anggota KWT dapat ditingkatkan melalui pendidikan non formal seperti proses pemberdayaan melalui kegiatan penyuluhan.

\section{Pengaruh Fungsi Kelompok Wanita Tani pada Keberdayaan}

Fungsi kelompok wanita tani berpengaruh nyata terhadap keberdayaan kelompok wanita tani. Hasil uji beta tersebut berarti $X_{2}$ memiliki pengaruh dominan terhadap $\mathrm{Y}$. Sebagian besar responden menilai bahwa fungsi kelompok wanita tani termasuk kedalam kategori sedang $(60,38 \%)$ sebanyak 32 orang. Hal ini dapat diartikan bahwa kelompok wanita tani yang ada di Kecamatan Palimanan keberadaannya cukup berperan dalam kegiatan usahatani.

Sesuai dengan Permentan No. 82 Tahun (2013), yaitu kelompok tani merupakan wadah belajar mengajar bagi anggota guna meningkatkan pengetahuan, sikap, dan keterampilan agar tumbuh dan berkembang menjadi usaha tani yang mandiri sehingga dapat meningkatkan produktivitas, pendapatan serta kehidupan yang lebih baik, selain itu kelompok tani merupakan tempat untuk memperkuat kerjasama baik di antar sesama petani dalam poktan dan antar poktan maupun dengan pihak lain. selaras dengan hasil kajian Ella et al. (2019) menghasilkan fungsi kelompok tani berpengaruh terhadap tingkat keberdayaan dan hasil Effendy \& Mustofa (2020) kelompok tani memberikan pengaruh terhadap kelembagaan petani.

\section{Pengaruh Dukungan Layanan Penyuluhan pada Keberdayaan}

Dukungan layanan penyuluhan berpengaruh nyata terhadap peningkatan keberdayaan kelompok wanita tani dalam memanfaatkan lahan pekarangan. Sebagian besar responden menilai dukungan layanan penyuluhan masuk pada kategori sedang sebanyak 32 orang dengan persentase $60,38 \%$. $\mathrm{Hal}$ tersebut berarti bahwa layanan penyuluhan yang diselenggarakan oleh pihak penyuluh maupun BPP belum berjalan dengan baik. Semakin tinggi peran penyuluh, ketepatan metode penyuluhan, kesesuaian materi penyuluhan, frekuensi penyuluhan dan ketersediaan informasi penyuluhan maka keberdayaan KWT akan menjadi tinggi pula.

Penyuluh pertanian menurut Wardani dan Anwarduin (2018) memiliki peran sebagai fasilitator, komunikator, motivator dan konsultan. Penyuluh pertanian memiliki tugas melakukan pembinaan terhadap petani dengan tujuan meningkatkan pengetahuan, sikap dan keterampilan petani (Anwarudin et al, 2020). Akan tetapi keberadaan penyuluhan pertanian yang terus berfluktuasi seperti detak jantung yang naik turun (Pradiana et al. 2020). Harniati dan Anwarudin (2018), menyampaikan bahwa intensitas dan pemanfaatan teknologi informasi akan meningkatkan aksesibilitas petani ke pihak luar.

$\begin{array}{cr}\begin{array}{c}\text { Pengaruh Dukungan } \\ \text { terhadap Keberdayaan } \\ \text { Dukungan }\end{array} & \text { Lingkungan } \\ \text { berpengaruh nyata } & \begin{array}{r}\text { lingkungan } \\ \text { terhadap }\end{array}\end{array}$


peningkatan keberdayaan kelompok wanita tani dalam memanfaatkan lahan pekarangan. Sebagian besar responden menilai dukungan lingkungan masuk pada kategori sedang sebanyak 36 orang dengan persentase $67,92 \%$. Hal tersebut berarti bahwa dukungan lingkungan yang ada di wilayah Kecamatan Palimanan berpengaruh positif.. Semakin tinggi sumberdaya lahan, dukungan pemerintah dan lembaga agribisnis maka keberdayaan KWT akan menjadi tinggi pula.

Dayat dan Anwarudin (2020) melaporkan dalam penelitianya bahwa dukungan pemerintah sudah bisa dinikmati petani seperti adanya pelatihan, bantuan modal usaha dan sarana prasarana walaupun belum optimal dan merata. Dukungan lingkungan terdiri dari sumberdaya lahan, dukungan pemerintah dan lembaga agribisnis. Dukungan pihak luar terhadap peningkatan kapasitas kelembagaan kelompok tani sangat diperlukan dalam proses peningkatkan kapasitas pengurus dan anggota kelompok tani (Ruhimat 2017).

\section{Strategi pemberdayaan anggota kelompok wanita tani}

Pemberdayaan merupakan upaya untuk meningkatkan kemampuan petani dalam berusahatani dengan memanfaatkan potensi yang ada baik dari dalam diri petani maupun lingkungannya untuk menjadikan petani yang mandiri dan berdaya saing. Berdasarkan hasil penelitian ini ditemukan bahwa keberdayaan anggota kelompok wanita melalui optimalisasi pekarangan pangan lestari berada pada kategori sedang. Dengan demikian hasil temuan ini bisa dijadikan acuan bagi penyuluh serta pemerintah dalam meningkatkan keberdayaan anggota KWT dalam pemanfaatan lahan pekarangan. Strategi dirumuskan dengan melihat hasil analisis faktor yang berpengaruh terhadap keberdayaan anggota KWT melalui optimalisasi pekarangan pangan lestari.
Adapun strategi yang bisa dilakukan untuk meningkatkan keberdayaan anggota kelompok wanita tani melalui optimalisasi pekarangan pangan lestari. Melakukan diskusi bersama-sama dengan melakukan pendekatan orang dewasa dan berbagi pengalaman sehingga responden dapat lebih menerima semua informasi yang disampaikan dan dapat mengadopsi suatu inovasi, Meningkatkan peran penyuluh seperti melakukan kegiatan konsultasi bisa dilakukan dengan berbagai cara seperti dengan memberikan layanan komunikasi via telepon, WhatsApp, dan media sosial lainya. Memilih metode penyuluhan yang tepat, materi yang dipilih harus sesuai dan meningkatkan frekuensi penyuluhan. Adanya dukungan dari lembaga agribisnis dan pemerintah sebagai penyediaan sarana prasarana pertanian. Meningkatkan fungsi kelompok wanita tani. Kelompok wanita tani harus berperan meningkatkan keberdayaan anggota KWT melalui kegiatan-kegiatan yang melibatkan anggota secara partisipatif anggota KWT mengikuti kegiatan tersebut. Ketua maupun pengurus kelompok wanita tani harus berperan menjadi leader dalam kelompok wanita tani tersebut. Ketua ataupun pengurus harus berperan menjadi pusat informasi atau jembatan anggota KWT penyuluh pertanian.

\section{Peningkatan}

keberdayaan

kelompok wanita tani terhadap usaha bidang pertanian melalui pemanfaatan lahan pekarangan melalui: Peningkatan kemampuan memanfaatkan lahan pekarangan, peningkatan kemampuan mengakses informasi, peningkatan menerapkan teknologi, peningkatan kemampuan mengambil keputusan dilakukan dengan dukungan layanan penyuluhan dan fungsi kelompok wanita tani. Dengan demikian langkah awal yang harus dilakukan untuk meningkatkan keberdayaan kelompok wanita tani yaitu dengan melihat rangking terkecil dari indikator yang terlibat dalam penelitian untuk dilakukan penyuluhan. 


\section{Petak Percontohan}

Petak percontohan dapat dijadikan sebagai strategi dalam menarik perhatian anggota KWT dalam memanfaatkan lahan pekarangan. Petak percontohan dapat didesain dengan beragam macam tanaman dan juga ditata dengan baik, sehingga ketika anggota KWT ataupun sasaran yang dituju melihat petak percontohan tersebut mereka merasa tergugah dan ingin menerapkan hal tersebut di lahan pekarangan rumahnya. Menanam langsung di bedengan, pot/polybag dan menggunakan teknik vertikultur terdapat beberapa macam perbedaan yaitu kemudahan dalam perawatan, keindahan dalam penataan dan keanekaragaman hasil panen.

Berdasarkan data analisis preferensi, anggota KWT lebih tertarik dengan model pertanaman vertikultur. Rak bertingkat yang tersusun bisa ditanami dengan berbagai jenis sayuran. Menambah keindahan di lahan pekarangan, sanitasi lingkungan yang cukup baik dan hasil panen dengan Tabel 7. Rancangan Penyuluhan

\begin{tabular}{|c|c|c|c|c|c|}
\hline Keadaan & Tujuan & Masalah & Sasaran & Materi & Media \\
\hline $\begin{array}{l}\text { Anggota KWT } \\
\text { memiliki lahan } \\
\text { pekarangan } \\
\text { yang sempit }\end{array}$ & $\begin{array}{l}\text { Meningkatkan } \\
\text { pemahaman } \\
\text { mengenai } \\
\text { budidaya } \\
\text { lahan sempit }\end{array}$ & $\begin{array}{l}\text { Rendahnya } \\
\text { pemahaman } \\
\text { mengenai } \\
\text { budidaya di } \\
\text { lahan sempit }\end{array}$ & $\begin{array}{l}\text { KWT Rukun } \\
\text { Lestari, } \\
\text { KWT Desi } \\
\text { Sri, KWT } \\
\text { Nusa Indah }\end{array}$ & $\begin{array}{l}\text { Budidaya } \\
\text { secara } \\
\text { vertikultur }\end{array}$ & $\begin{array}{l}\text { Pemberian } \\
\text { poster/leaflet }\end{array}$ \\
\hline $\begin{array}{l}\text { Tidak } \\
\text { melakukan } \\
\text { pemupukan } \\
\text { susulan }\end{array}$ & $\begin{array}{l}\text { Meningkatkan } \\
\text { pemahaman } \\
\text { mengenai } \\
\text { pemupukan } \\
\text { susulan }\end{array}$ & $\begin{array}{l}\text { Rendahnya } \\
\text { pemahaman } \\
\text { mengenai } \\
\text { pemupukan } \\
\text { susulan }\end{array}$ & $\begin{array}{l}\text { KWT Rukun } \\
\text { Lestari, } \\
\text { KWT Desi } \\
\text { Sri, KWT } \\
\text { Nusa Indah }\end{array}$ & $\begin{array}{l}\text { Pembuatan } \\
\text { pupuk } \\
\text { organik } \\
\text { limbah } \\
\text { dapur }\end{array}$ & $\begin{array}{l}\text { Ceramah dan } \\
\text { demonstrasi } \\
\text { cara, } \\
\text { pemberian } \\
\text { leaflet/brosur }\end{array}$ \\
\hline $\begin{array}{l}\text { Kurangnya } \\
\text { pemahaman } \\
\text { mengenai } \\
\text { pengendalian } \\
\text { hama }\end{array}$ & $\begin{array}{l}\text { Meningkatkan } \\
\text { pemahaman } \\
\text { mengenai } \\
\text { pengendalian } \\
\text { hama }\end{array}$ & $\begin{array}{l}\text { Rendahnya } \\
\text { pemahaman } \\
\text { teknis } \\
\text { pengendalian } \\
\text { hama }\end{array}$ & $\begin{array}{l}\text { KWT Rukun } \\
\text { Lestari, } \\
\text { KWT Desi } \\
\text { Sri, KWT } \\
\text { Nusa Indah }\end{array}$ & $\begin{array}{l}\text { Pembuatan } \\
\text { pestisida } \\
\text { nabati }\end{array}$ & $\begin{array}{l}\text { Ceramah dan } \\
\text { demonstrasi } \\
\text { cara yang } \\
\text { dikemas } \\
\text { dalam video, } \\
\text { pemberian } \\
\text { leaflet/brosur }\end{array}$ \\
\hline
\end{tabular}

Sumber: Data Primer (2021)

Simpulan dan Saran

Simpulan kualitas bagus karena mendapat penyinaran matahari yang cukup baik. Responden sebanyak 62,5 \% lebih tertarik model pertanaman vertikultur untuk tanaman bayam. Terdapat $67,5 \%$ responden lebih tertarik model pertanaman vertikultur untuk tanaman sawi. Sebagian besar responden 57,5\% lebih tertarik model pertanaman bedengan untuk tanaman cabai dan terong. Hasil panen bayam dan terong lebih banyak di bedengan masingmasing sebanyak 2.850 gram dan 1.000 gram, serta tanaman sawi dan cabai lebih banyak di rak bertingkat masinggram.

\section{Pelaksanaan Kegiatan Penyuluhan}

Berdasarkan strategi yang telah dirumuskan, penyuluhan dilakukan secara partisipatif dimana anggota kelompok wanita tani menjadi aktor dan ikut serta dalam kegiatan. Kemudian dengan mengoptimalkan media yang ada dan dengan metode yang mudah diterapkan. masing sebanyak 2.800 gram dan 1.960

Berdasarkan hasil penelitian mengenai pemberdayaan kelompok wanita tani melalui pemanfaatan 
pekarangan pangan lestari (P2L) yang telah dilaksanakan di Kecamatan Palimanan Kabupaten Cirebon, dapat disimpulkan sebagai berikut:

1. Keberdayaan anggota kelompok wanita tani melalui optimalisasi pekarangan pangan lestari di Kecamatan Palimanan pada tingkatan sedang. Anggota kelompok wanita tani sudah mampu mengakses informasi melalui media elektronik. Mampu memanfaatkan teknologi dengan cara budidaya di lahan pekarangan cukup baik. Serta mampu mengambil keputusan dalam pemanfaatan pekarangan bersama keluarga.

2. Faktor-faktor yang mempengaruhi keberdayaan kelompok wanita tani, diantaranya adalah umur, fungsi kelompok wanita tani dukungan layanan penyuluhan dan dukungan lingkungan.

3. Strategi untuk meningkatkan keberdayaan kelompok wanita tani melalui optimalisasi pekarangan pangan lestari yaitu: 1) Melakukan diskusi bersamasama dengan melakukan pendekatan orang dewasa dan berbagi pengalaman 2) Melaksanakan kegiatan pemanfaatan lahan pekarangan secara intensif dengan meningkatkan kualitas penyuluhan 3) Meningkatkan fungsi kelompok wanita tani diantaranya: kelas belajar, wahana kerjasama, dan unit produksi. 4) Peningkatan keberdayaan kelompok wanita tani terhadap usaha bidang pertanian melalui: Peningkatan kemampuan memanfaatkan lahan pekarangan (pengetahuan, keterampilan, sikap), peningkatan kemampuan mengakses informasi, peningkatan menerapkan teknologi, peningkatan kemampuan mengambil keputusan.

\section{Saran}

Adapun saran yang dapat disampaikan penulis dalam kegiatan penelitian ini adalah sebagai berikut:

1. Kelompok wanita tani diharapkan dapat mengoptimalkan lahan pekarangan untuk menanam komoditas pertanian sehingga pengetahuan, sikap dan keterampilan dapat terus meningkat dan usaha secara berkelanjutan

2. Diharapkan adanya dukungan secara keberlanjutan dari Balai Penyuluhan Pertanian (BPP) kepada anggota KWT mengenai pemanfaatan lahan pekarangan secara berkelanjutan.

\section{Daftar Pustaka}

[BKP] Badan Ketahanan Pangan Kementerian Pertanian. 2020. Petunjuk Teknis bantuan Pemerintah Kegiatan

Pekarangan Pangan Lestari Tahun 2020. Jakarta: Kementerian Pertanian.

[BPP] Balai Penyuluhan Pertanian. 2020. Programa BPP Palimanan. Kecamatan Palimanan: BPP Kecamatan Palimanan. 
[BPS] Badan Pusat Statistik. 2020. Kabupaten Cirebon dalam Angka. Kabupaten Cirebon: BPS Kabupaten Cirebon.

[BPS] Badan Pusat Statistik. 2021. Kabupaten Cirebon dalam Angka. Kabupaten Cirebon: BPS Kabupaten Cirebon.

[BPS] Badan Pusat Statistik. 2020. Kecamatan Palimanan dalam Angka. Kabupaten Cirebon: BPS Kabupaten Cirebon.

[RI] Indonesia, N. K. 2017. Peraturan Pemerintah Nomor 17 Tahun 2015 tentang Ketahanan Pangan dan Gizi. Jakarta: Lembaran Negara Kesatuan Republik Indonesia.

[Kementerian Pertanian] Kementerian Pertanian. 2018. Petunjuk Teknis Optimalisasi Pemanfaatan Lahan Pekarangan Melalui Kawasan Rumah Pangan Lestari (KRPL). [Diunduh pada 11 Januari 2020]. Tersedia pada: https://www.bkp.pertanian.go.id/

Anwarudin O, Sumardjo, Satria A, Fatchiya A. 2020. Peranan Penyuluh Pertanian dalam Mendukung Keberlanjutan Agribisnis Petani Muda di Kabupaten Majalengka. Jurnal Agribisnis Terpadu. 13(1):17-36.

Ashari, Saptana, Purwantini, T.B. 2012. Potensi dan Prospek Pemanfaatan Lahan Pekarangan untuk Mendukung Ketahanan Pangan. Forum Penelitian Agro Ekonomi, 30(1), 13-30.

Dwiratna, N. P. S., Widyassanti, A., dan Rahmah, D.M. 2016. Pemanfaatan Lahan Pekarangan dengan Menerapkan Konsep Kawasan Rumah Pangan Lestari. Dharmakarya: Jurnal Aplikasi Ipteks untuk Masyarakat. 5(1), 1922.

Farahdiba Z., Achdiyat, Sarisewi TR. 2020. Peran Anggota Kelompok Wanita Tani dalam Pemanfaatan Lahan Pekarangan di Kelurahan Pasih Putih, Kecamatan Sawangan, Kota Depok. Jurnal Inovasi Pertanian. 1(3):535-544.

Harniati H, Anwarudin O. 2018. The Interest and Action of Young Agricultural Enterpreneur on Agribusinessin Cianjur Regency West Java. Jurnal Penyuluhan. 14(2): 189-198.

Hulyatussyamsiah S, Hartono R, Anwarudin O. 2019. Adopsi Pemupukan Berimbang Padi Sawah Melalui Penggunaan Urea Berlapis Arang Aktif. Jurnal Penyuluhan Pertanian. 14(2): 1 17.

Irwan., Sarwadi A. 2015. sLanskap Pekarangan Produktif di Permukiman Perkotaan dalam Mewujudkan Lingkungan Binaan Berkelanjutan. Prosiding SEMNASTEK Fakultas Teknik. Universitas Muhammadiyah Jakarta.

Jalieli, A. 2013. Tingkat Partisipasi Dan Keberdayaan Petani Alumni Program SI-PTT Di Desa Gegesik Wetan Kabupaten Cirebon. Institut Pertanian Bogor.

Kartika, T. 2018. Pemanfaatan Tanaman Hias Pekarangan Berkhasiat Obat di Kecamatan Tanjung Batu. Sainmatika: Jurnal 
IImiah Matematika Dan IImu Pengetahuan Alam. 15(1), 4855.

Mardikanto, Totok dan Soebiato. 2013. Pemberdayaan Masyarakat Dalam Perspektif Kebijakan Publlik. Bandung: Alfabeta.

Masalamate, et al. 2015. Perilaku Petani di Sekitar Hutan Lindung Soputau dan Manimprok Kecamatan

Ratahan Kabupaten Minahasa Tenggara. Universitas Sam Ratulangi Manado.

Metalisa R., Saleh A., dan Tjitropranoto P. 2014. Peran Ketua Kelompok Wanita Tani dalam Pemanfaatan Lahan Pekarangan yang Bekelanjutan. Jurnal Penyuluhan. 10 (2), 158170.

Pambudi, P. A. 2020. Pandemi Covid19: Refleksi Pentingnya Optimasi Lahan Pekarangan Sebagai Penyokong Kemandirian Pangan Dan Kesehatan Keluarga. EnviroScienteae. $16 \quad$ (3), 408-423.

Permana. Y., Effendy. L., dan Tassim. M. B. 2020. Pemberdayaan Kelompok Wanita Tani melalui Pemanfaatan Lahan Pekarangan menuju Rumah Pangan Lestari di Kecamatan Cikedung Indramayu. Jurnal Inovasi Penelitian. 1 (3), 419-428.

Pradiana W, Anwarudin O, Maryani A. 2020. Determining Factors Of The Development

Of Agricultural Extension Office As A Knot For Coordinating Agricultural Development. International Journal Of Scientific \& Technology Research
(IJSTR). 9(3): 3766-3773.

Puspitasari, Nurmalina N., Fariyanti A., dan Marendra A. K. 2018. Pengaruh Faktor Internal dan Eksternal Terhadap Perilaku Kewirausahaan dan Dampaknya Terhadap Kinerja Usaha

Petani Anggrek. Jurnal Horikultura. 28 (02):299-310.

Sadono, Dwi. 2012. Model Pemberdayaan Petani dalam Pengelolaan Usahatani Padi di Kabupaten Karawang dan Cianjur Provinsi Jawa Barat. [Disertasi]. (ID) Institut Pertanian Bogor.

Saputra, R. C., Indardi., \& Widodo, A. S. 2016. Faktor-faktor yang mempengaruhi tingkat penerapan teknologi pertanian padi organik. Universitas Muhammadiyah Yogyakarta.

Sari, Resti Yulanda, et al. 2016. Perbandingan Tigkat Pengetahuan Petani Sebelum dan Sesudah menggunakan Media Visual dan Media Audiovisual terhadap Petani di Kelurahan Telaga Samsam Kecamatan Kandis Kabupaten Siak. Jurnal Jom Faperta: Vol. 3 No. 1. Universitas Riau.

Setiawan, Satrio Adi. 2010. Pengaruh Umur, Pendidikan, Pendapatan, Pengalaman Kerja, dan Jenis Kelamin terhadap Lama Mencari Kerja Bagi tenaga kerja Terdidik di Kota Magelang. Universitas Diponegoro.

Suaedi, Nurhilal, Musnidar I. 2013. Peran Wanita Tani dalam Pemanfaatan Lahan Pekarangan Untuk Tanaman Pangan. Jurnak 
Pertanian

Berkelanjutan.

Universitas

Cokroaminoto

Palopo.

Suyadi S. 2018. Kepemimpinan Tokoh Informal Dalam Peningkatan Kapasitas Petani Agroforestri Di Lingkungan Taman Nasional Gunung Ciremai. [disertasi]. Bogor: Institut Pertanian Bogor.
Zulvera, et al. 2014. Faktor-Faktoryang

Berhubungan

Dengan

Keberdayaan Petani Sayuran

Organik di Kabupaten Agam dan Tanah Datar, Provinsi Sumatera Barat. MIMBAR: Jurnal Sosial dan

Pembangunan 30 (2): 149-158 